УДК 616.366/.367-003.7-089.87-072.1-06:616.361-001.35

DOI 10.11603/2414-4533.2019.4.10714

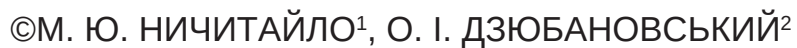

ДУ “Національний інститут хірургії та трансплантології імені О.О. Шалімова НАМН України"1

Тернопільський національний медичний університет імені І. Я. Горбачевського МОЗ України²

\title{
Обгрунтування термінів виконання лапароскопічної холецистектомії на основі темпу декомпресії жовчних шляхів при обтураційній жовтяниці, зумовленій холецистохоледохолітіазом
}

\begin{abstract}
Мета роботи: обґрунтувати оптимальні терміни виконання лапароскопічної холецистектомії після попереднього ендоскопічного транспапілярного втручання у хворих з обтураційною жовтяницею, зумовленою холецистохоледохолітіазом, шляхом визначення темпу декомпресії жовчних шляхів та динаміки відновлення показників функціонального стану печінки.

Матеріали та методи. У 59 (33,34 \%) пацієнтів апробовано двохетапну методику (трансбіліарне ендоскопічне дренування+ лапароскопічна холецистектомія) з визначенням оптимальних термінів виконання радикальної операції на основі динаміки білірубіну та темпу декомпресії після ендоскопічного втручання.

Результати досліджень та їх обговорення. Темп відповіді жовтяниці при проведенні транспапілярної біліарної декомпресії при легкому ступені жовтяниці на 1-3 добу після операції був помірним (B=14,3). Тоді як на 4-6 добу темп відповіді відповідав затяжному $(B=9,62)$. Дослідження у групі хворих із середнім ступенем тяжкості жовтяниці показало, що темп відповіді жовтяниці на транспапілярну декомпресію у пацієнтів на 1-3 добу становив (B=19,8), що відповідає швидкому темпу, а на 4-6 добу після декомпресії відмічено трансформацію швидкого темпу в помірний ( $\mathrm{B}=11,14)$. У пацієнтів 3 тяжким ступенем жовтяниці спостерігали на 1-3 добу після операції затяжний темп (B=9,66), тоді як на 4-6 добу після декомпресії темп відповіді жовтяниці трансформувався в швидкий $(\mathrm{B}=20,66)$. У хворих із легким ступенем жовтяниці при помірно-затяжному темпі декомпресії другий етап операції доцільно виконувати в перші три доби після декомпресійного періоду; при середньому ступені і при помірному темпі декомпресії - на 4-6 добу після попередньої операції; при тяжкому ступені і при швидкому темпі на 4-6 добу після декомпресії - 3 14 доби після декомпресійного періоду або лікування завершується першим етапом.
\end{abstract}

Ключові слова: лапароскопічна холецистектомія; декомпресія; жовчні шляхи; обтураційна жовтяниця; холедохолітіаз.

Постановка проблеми і аналіз останніх досліджень та публікацій. Холедохолітіаз, ускладненням якого $є$ обтураційна жовтяниця з рівнем операційної летальності на висоті жовтяниці від 7 до 20 \%, є актуальною проблемою біліарної хірургії [4]. Причиною летальності є “синдром біліарної декомпресії” або “синдром швидкого скидання”, що призводить до морфологічних і функціональних змін печінки.

В остатні десятиліття в хірургії жовчнокам'яної хвороби, ускладненої холедохолітіазом, накреслилися три основні тактичні підходи: “відкриті одноетапні” операції на жовчному міхурі та позапечінкових жовчних протоках; “одноетапні” методи - в обсязі лапароскопічної холецистектомії в поєднанні з лапароскопічними операціями на жовчних протоках; “двохетапні” методи, що включають як перший етап - транспапілярну декомпресію жовчних протоків в обсязі папілотомії з наступною лапароскопічною холецистектомією або холецистектомія 3 міні-доступу [2, 5]. Терміни виконання другого радикального хірургічного втручання - лапароскопічної холецистекотомії і до сьогодні дискутуються у зв'язку з частими явищами печінкової недостатності викликаної синдромом швидкої біліарної декомпресії [3, 6, 7].
Дані різних авторів вказують на можливість його виконання і в день виконання ендоскопічної папілотомії, через 24-72 години після біліарної декомпресії або навіть через 3-5 днів.

Мета роботи: обгрунтувати оптимальні терміни виконання лапароскопічної холецистектомії після попереднього ендоскопічного транспапілярного втручання у хворих з обураційною жовтяницею, зумовленою холецистохоледохолітіазом, шляхом визначення темпу декомпресії жовчних шляхів і динаміки відновлення показників функціонального стану печінки.

Матеріали і методи. Проведено аналіз результатів хірургічного лікування у 177 хворих з ускладненим холедохолітіазом. У віці 20-59 років був 91 хворий (51,4 \%), 60-74 роки - 71 (40,1 \%), 75-89 років - 15 пацієнтів (8,5 \%). Із 177 хворих 3 явищами холедохолітіазу у 140 (79,10 \%) спостерігали обтураційну жовтяницю. Характер операційних втручань у хворих на холецистохоледохолітіаз наведено на рисунку 1.

Усіх пацієнтів було поділено на 3 групи: хворі 3 тривалістю жовтяниці до 3 діб із моменту появи жовтяниці, до 5 діб та до 7 діб. Крім того, включено контрольну групу $(\mathrm{n}=12)$ здорових обстежува- 


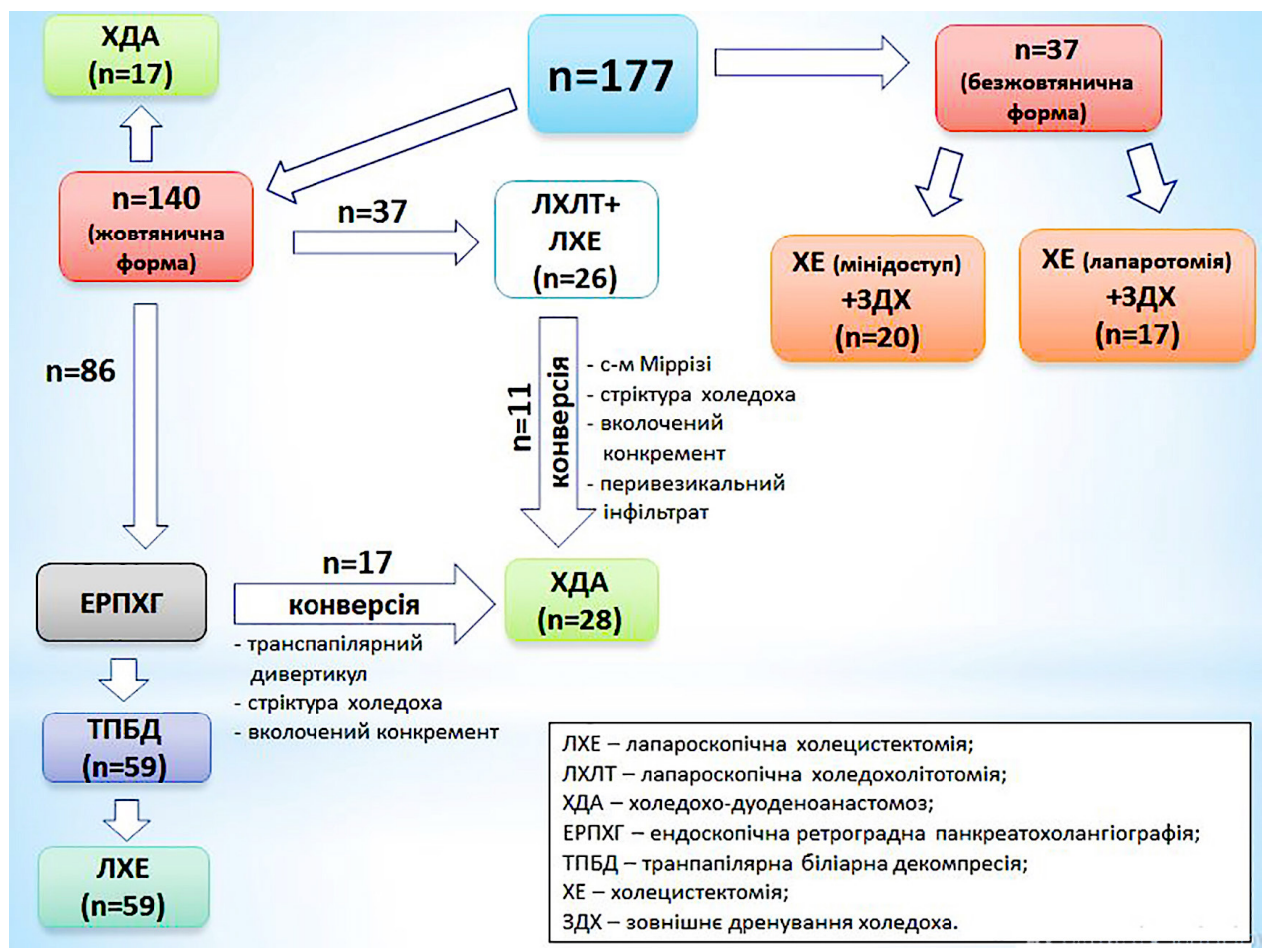

Рис. 1. Хірургічна тактика у пацієнтів із холецистохоледохолітіазом (n=177).

них. Було досліджено біохімічні показники холестазу: білірубінемію за методом Ендрасіка-Грофа, активність лужної фосфатази (ЛФ); показники цитолітичного синдрому - активність аспартатамінотрансферази (АсАТ) і аланінамінотрансферази (АлАТ) до проведення операційного втручання, а також на 3-тю, 5-ту та 7-му доби після проведення декомпресії жовчних проток.

3 метою з'ясування темпу відтоку жовчі було використано модифіковану проф. Э. И. Гальпериным и соавт. [1] формулу відповіді жовтяниці на декомпресію жовчних проток, запропоновану T. Shimizu i K. Yohsida. Графік зниження білірубіну відповідає нелінійній функції, а функції натурального логарифму. Темп відповіді жовтяниці на декомпресію оцінювали таким чином (показник Beta): > $5 \leq 10$ затяжний темп, > $10 \leq 15$ - помірний, $>15 \leq 20$ - швидкий темп.

Статистичну обробку отриманих результатів виконано у відділі системних досліджень Тернопільського національного медичного університету в програмному пакеті Statsoft STATISTICA. Багатофакторний аналіз проведено за допомогою методу лінійної регресії та квартильного методу. Розраховували середнє значення (M) і стандартну похибку середнього (m). Залежно від нормальності розподілу вибірки аналіз відмінностей між двома групами здійснювали за допомогою t-тесту або U-критерію Манна - Уїтні. Відмінності вважалися статистично значимими при $\mathrm{p}<0,05$.
Результати досліджень та їх обговорення. Проведено аналіз динаміки біохімічних показників холестазу та цитолізу сироватки крові в контрольній групі і після ендоскопічної транспапілярної декомпресії жовчних проток у 59 хворих із різним рівнем гіпербілірубінемії і в різні післядекомпресійні строки. Встановлено достовірне зниження рівня загального і прямого білірубіну крові відносно доопераційних показників. У пацієнтів із рівнем гіпербілірубінемії до 100 мкмоль/л зниження загального і прямого білірубіну на 1-3 добу після операції, відповідно, склало на 52,2 і 28,2 \% ( $<<0,01)$, а на 4-6 добу - на 62,9 і 65,0 \% ( $<<0,01)$ відповідно.

Темп відповіді жовтяниці при проведенні транспапілярної біліарної декомпресії на 1-3 добу після операції був помірним $(\mathrm{B}=14,3)$. Тоді як на 4-6 добу темп відповіді відповідав затяжному $(\mathrm{B}=9,62)$. Показники лужної фосфатази були достовірно знижені на 1-3 і 4-6 доби, відповідно, на 13,8 і 26,1 \% порівняно з доопераційними показниками $(\mathrm{p}<0,01)$.

Дослідження динаміки рівня загального і прямого білірубіну в групі хворих із середнім ступенем тяжкості жовтяниці (гіпербілірубінемія від 100 до 200 мкмоль/л) показало, що на 1-3 добу після транспапілярної біліарної декомпресії рівень загального і прямого білірубіну достовірно знизився на 58,9 і 49,9 \% відповідно ( $<$ 0,01). Вже на 4-6 добу після операції дані показники знизи- 
лися, на 90,1 і 87,2 \% відповідно (p<0,01). Спостерігали зниження рівня лужної фосфатази на 1-3 добу на 30,0 \% (p<0,01) і на 4-6 добу на - 31,7 \% ( $<0,01)$ після декомпресії порівняно $з$ доопераційними показниками. Темп відповіді жовтяниці на транспапілярну декомпресію у пацієнтів на 1-3 добу становив $(\mathrm{B}=19,8)$, що відповідає швидкому темпу, а на 4-6 добу після декомпресії відмічено трансформацію швидкого темпу в помірний $(\mathrm{B}=11,14)$.

У пацієнтів із тяжким ступенем жовтяниці (рівень гіпербілірубінемії більше 200 мкмоль/л) спостерігали зниження рівня загального i прямого білірубіну на 1-3 доби після декомпресії на 48,7 і 54,5 \% відповідно, ( $<<0,01)$, а на 4-6 добу - на 90,7 і 91,3 \% відповідно ( $<<0,01)$, порівняно з вихідним рівнем білірубіну. У вказаної групи показник лужної фосфатази знизився на 21,4 i 33,3 \% $(\mathrm{p}<0,01)$ в 1-3 і 4-6 добу після декомпресії відповідно. Темп відповіді жовтяниці на декомпресію в 1-3 доби після операції був затяжним $(B=9,66)$, тоді як на 4-6 добу після декомпресії темп відповіді жовтяниці трансформувався в швидкий $(\mathrm{B}=20,66)$.

Отже, у хворих з легким ступенем жовтяниці після ендоскопічного транспапілярного втручання при помірно-затяжному (сповільненому) темпі декомпресії другий етап радикальної операції доцільно виконувати в перші три доби післядекомпресійного періоду; при середньому ступені та при помірному темпі декомпресії - з 4-6 доби, а при тяжкому ступені і при швидкому темпі з 4-6 доби після декомпресії - з 14 доби післядекомпресійного періоду або лікування завершується першим етапом у зв'язку з ризиком розвитку синдрому “швидкої” декомпресії (табл. 1).

Таблиця 1. Терміни виконання лапароскопічної холецистектомії залежно від темпу декомпресії жовчних шляхів

\begin{tabular}{||c|c|c|c||}
\hline \hline \multirow{2}{*}{$\begin{array}{c}\text { Ступені тяжкості } \\
\text { жовтяниці }\end{array}$} & $\begin{array}{c}\text { Темп декомпресії жовчних шляхів } \\
\text { у післядекомпресійних періодах }\end{array}$ & \multirow{2}{*}{ Терміни радикальної операції } \\
\cline { 1 - 3 } & $1-3$ доба & $4-6$ доба & \\
\hline Легкий & помірний & затяжний & 1-3 доба \\
\hline Середній & швидкий & помірний & 4-6 доба \\
\hline Тяжкий & затяжний & швидкий & після 14 днів або як заключний етап операції \\
\hline \hline
\end{tabular}

Двохетапна тактика апробована у 59 хворих з обураційною жовтяницею на грунті холедохолітіазу. 322 осіб з легким ступенем жовтяниці у 17 пацієнтів лапароскопічна холецистектомія виконана на 1-3 добу після проведеної транспапілярної біліарної декомпресії, а у 5 - ЛХЕ була виконана в межах 4-6 доби у зв'язку з наявністю післяопераційного панкреатиту та кровотеча після папілотомії (консервативний гемостаз). У 9 пацієнтів з тяжким ступенем жовтяниці та у 4 з середнім ступенем у зв'язку з “швидким” темпом декомпресії та явищами печінкової недостатності, після корегуючої дезінтоксикаціної терапії, ЛХЕ відтерміновано на 14 днів.

Висновки. 1. Темп декомпресії жовчних шляхів після ендоскопічного транспапілярного втручання не відзначається стабільністю і характеризується у хворих із легким ступенем жовтяниці протягом перших трьох днів післядекомпресійного періоду як помірний $(B=14,6) 3$ переходом 3
4-6 доби в затяжний $(B=9,6)$. У хворих із середнім ступенем в 1-3 доби після декомпресії спостерігався швидкий темп декомпресії $(\mathrm{B}=19,6) 3$ трансформацією в помірний (B = 11) з 4-6 доби, а у хворих з тяжким ступенем жовтяниці - затяжний (1-3 доба) з переходом у швидкий темп з 4-6 доби післядекомпресійного періоду.

За темпом декомпресії жовчних шляхів і відновленням показників печінково-клітинної функції обгрунтовані оптимальні терміни виконання холецистектомії після попереднього відеоендоскопічного транспапілярного біліарного втручання. У хворих із легким ступенем жовтяниці при помірно-затяжному темпі декомпресії другий етап операції доцільно виконувати в перші три доби післядекомпресійного періоду; при середньому ступені і при помірному темпі декомпресії - на 4-6 доби після попередньої операції; при тяжкому ступені і при швидкому темпі на 4-6 доби після декомпресії - 314 доби післядекомпресійного періоду або лікування завершується першим етапом. 


\section{СПИСОК ЛІТЕРАТУРИ}

1. Гальперин Э. И. Темп декомпрессии желчных протоков при механической желтухе опухолевой этиологии / Э. И. Гальперин, А. Е. Котовский, О. Н. Момунова // Хирургия. Журнал им. Н.И. Пирогова. - 2011. - № 8. - С. 33-40.

2. Каніковський О. Є. Способи біліарної декомпресії при механічній жовтяниці у віковому аспекті / О. Є. Каніковський, Я. В. Карий, Ю. В. Бабійчук // Клінічна анатомія та оперативна хірургія. - 2017. - Т. 16, № 2. - С. 52-55.

3. Predictive factors for long operative duration in patients undergoing laparoscopic cholecystectomy after endoscopic retrograde cholangiography for combined choledochocystolithiasis / R. Lee, H. Ha, Y. S. Han [et al.] // Surgical Laparoscopy, Endoscopy \& Percutaneous Techniques. - 2017. - Vol. 27 (6). P. 491.

4. Ничитайло М. Е. Лапароскопическая хирургия холедо- холитиаза / М. Е. Ничитайло // Здоровье Украины. - 2014. № 2. - С. 16-17.

5. Способи біліарної декомпресії при обтураційній жовтяниці у хворих поважного віку / М. Є. Ничитайло, О. Є. Каніковський, Я. В. Карий, Й. В. Бабійчук // Клин. хирургия. 2017. -№ 7. - C. 10-12.

6. Саволюк С. І. Дискусійні моменти вибору тактики та методу хірургічного лікування ускладнених форм непухлинної обтураційної жовтяниці / С. І. Саволюк, І. М. Вовчук, В. О. Лосєв // Вісник Вінницького національного медичного університету. - 2015. - Т. 19, № 1. - С. 125-130.

7. Timing of cholecystectomy after emergent endoscopic retrograde cholangiopancreatography for cholangitis / S. E. Severance, C. Feizpour, D. V. Feliciano [et al.] // The American Surgeon. - 2019. - Vol. 85 (8). - P. 895-899.

\section{REFERENCES}

1. Galperin, E.I., Kotovskiy, A.E., \& Momunova, O.N. (2011). Temp dekompressii zhelchnykh protokov pri mekhanicheskoy zheltukhe opukholevoy etiologii [Decompression rate of bile ducts with obstructive jaundice of tumor etiology]. Khirurgiya. Zhurnal im. N.I. Pirogova - Surgery. Journal named after N.I. Pirogov, 8, 33-40 [in Russian].

2. Kanikovskyi, O.Ye., Karyi, Ye.V., \& Babiichuk, Yu.V. (2017). Sposoby biliarnoi dekompresii pry mekhanichnii zhovtianytsi u vikovomu aspekti [Methods of billiar decompression in mechanical jaundice in age aspects]. Klinichna anatomiia ta operatyvna khirurhiia - Clinical Anatomy and Operative Surgery, 16 (2), 52-55 [in Ukrainian].

3. Lee, R., Ha, H., Han, Y.S., Jung, M.K., \& Chun, J.M. (2017). Predictive factors for long operative duration in patients undergoing laparoscopic cholecystectomy after endoscopic retrograde cholangiography for combined choledochocystol ithiasis. Surgical Laparoscopy, Endoscopy \& Percutaneous Techniques, 27 (6), 491.

4. Nichitaylo, M.E. (2014). Laparoskopicheskaya khirurgiya

kholedokholitiaza [Laparoscopic surgery for choledocholithiasis]. Zdorovye Ukrainy - Health of Ukraine, 2, 16-17 [in Russian]. 5. Nychytailo, M.Ye., Kanikovskyi, O.Ye., Karyi, Ya.V., \& Babiichuk, Y.V. (2017). Sposoby biliarnoi dekompresii pry obturatsiinii zhovtianytsi u khvorykh povazhnoho viku [Ways of billiar decompression in obturative jaundice in patients of senile age]. Klinicheskaya khirurgiya - Clinical Surgery, 7, 10-12 [in Ukrainian] 6. Savoliuk, S.I., Vovchuk, I.M., \& Losiev, V.O. (2015). Dyskusiini momenty vyboru taktyky ta metodu khirurhichnoho likuvannia uskladnenykh form nepukhlynnoi obturatsiinoi zhovtianytsi [Discussion points of the choice of tactics and method of surgical treatment of complicated forms of nontumoral obstructive jaundice]. Visnyk Vinnytskoho natsionalnoho medychnoho universytetu - Bulletin of Vinnytsia National Medical University, 19 (1), 125-130 [in Ukrainian]

7. Severance, S.E., Feizpour, C., Feliciano, D.V., Coleman, J., Zarzaur, B.L., \& Rozycki, G.F. (2019). Timing of cholecystectomy after emergent endoscopic retrograde cholangiopancreatography for cholangitis. The American Surgeon, 85 (8), 895-899.

Отримано 24.10.2019

Електронна адреса для листування: dzybanovskiyoi@tdmu.edu.ua

\section{YU. NYCHYTAILO ${ }^{1}$, O. I. DZIUBANOVSKYI}

O. Shalimov National Institute of Surgery and Transplantology, NAMS of Ukraine ${ }^{1}$

I. Horbachevsky Ternopil National Medical University²

\section{RATIONALE FOR THE TIMING OF LAPAROSCOPIC CHOLECYSTECTOMY ON THE BASIS OF THE RATE OF BILIARY TRACT DECOMPRESSION IN OBSTRUCTIVE JAUNDICE CAUSED BY CHOLEGYSTOCHOLEDOCHOLITHIASIS}

The aim of the work: to justify the optimal timing of laparoscopic cholecystectomy after previous endoscopic transpapillary intervention in patients with perturbed jaundice caused by cholecystocholedocholithiasis, by determining the rate of bile duct decompression and the dynamics of recovery of functional indicators of the liver.

Materials and Methods. In 59 (33.34 \%) patients, a two-stage technique (transbiliary endoscopic drainage + laparoscopic cholecystectomy) was tested, with optimal timing of radical surgery based on bilirubin dynamics and rate of decompression after endoscopic intervention.

Results and Discussion. The rate of jaundice response during transpapillary biliary decompression at mild jaundice at $1-3$ days after surgery was moderate $(B=14.3)$. Whereas on day $4-6$, the response rate was protracted $(B=9.62)$. The study in the group of patients with moderate severity of jaundice showed that the rate of response of jaundice to transpapillary decompression in patients at $1-3$ days 
was $(B=19$.), which corresponds to the fast pace, and at 4-6 days after decompression, the transformation of fast temp to moderate ( $B=11.14)$. In patients with severe jaundice, a prolonged rate of $1-3$ days after surgery was observed $(B=9.66)$, whereas at $4-6$ days after decompression, the response rate of jaundice was transformed into rapid $(B=20.66)$. In patients with mild jaundice with a moderate - prolonged rate of decompression, it is advisable to perform the second stage of surgery in the first three days after the decompression period; at an average degree and at a moderate rate of decompression - for 4-6 days after the previous operation; at a severe degree and at a rapid rate of 4-6 days after decompression - from 14 days after the decompression period or treatment ends with the first stage.

Key words: laparoscopic cholecystectomy; decompression; bile ducts; jaundice; choledocholithiasis.

\author{
М. Е. НИЧИТАЙЛО
}

ГУ “Национальный институт хирургии и трансплантологии имени А. А. Шалимова НАМН Украины"1 Тернопольский национальный медицинский университет имени И. Я. Горбачевского МОЗ Украины²

\title{
ОБОСНОВАНИЕ СРОКОВ ВЫПОЛНЕНИЯ ЛАПАРОСКОПИЧЕСКОЙ ХОЛЕЦИСТЭКТОМИИ НА ОСНОВЕ ТЕМПА ДЕКОМПРЕССИИ ЖЕЛЧНЫХ ПУТЕЙ ПРИ ОБТУРАЦИОННОЙ ЖЕЛТУХЕ, ОБУС.ЛОВЛЕННОЙ ХОЛЕЦИСТОХОЛЕДОХОЛИТИАЗОМ
}

\begin{abstract}
Цель работы: обосновать оптимальные сроки выполнения лапароскопической холецистэктомии после предварительного эндоскопического транспапилярного вмешательства у больных с обурационной желтухой, обусловленной холецистохоледохолитиазом, путем определения темпа декомпрессии желчных путей и динамики восстановления показателей функционального состояния печени.

Материалы и методы. В 59 (33,34 \%) пациентов апробировано двухэтапную методику (трансбилиарное эндоскопическое дренирование + лапароскопическая холецистэктомия) с определением оптимальных сроков выполнения радикальной операции на основе динамики билирубина и темпа декомпрессии после эндоскопического вмешательства.

Результаты исследований и их обсуждение. Темп ответа желтухи при проведении транспапилярной билиарной декомпрессии при легкой степени желтухи на 1-3 сутки после операции был умеренным (B = 14,3). Тогда на 4-6 сутки темп ответа отвечал затяжному $(B=9,62)$. Исследования в группе больных со средней степенью тяжести желтухи показало, что темп ответа желтухи на транспапилярну декомпрессию у пациентов на 1-3 сутки составлял (B = 19,8), что соответствует быстрому темпу, а на 4-6 сутки после декомпрессии отмечено трансформацию быстрого темпа в умеренный $(\mathrm{B}=11,14)$. У пациентов с тяжелой степенью желтухи наблюдали на 1-3 сутки после операции затяжной темп (B = 9,66), тогда как на 4-6 сутки после декомпрессии темп ответа желтухи трансформировался в быстрый $(B=20,66)$. У больных с легкой степенью желтухи при умеренно-затяжном темпе декомпрессии второй этап операции целесообразно выполнять в первые трое суток после декомпрессионного периода; при средней степени и при умеренном темпе декомпрессии - на 4-6 сутки после предыдущей операции; при тяжелой степени и при быстром темпе на 4-6 сутки после декомпрессии - с 14 суток после декомпрессионного периода или лечение завершается первым этапом.
\end{abstract}

Ключевые слова: лапароскопическая холецистэктомия; декомпрессия; желчные пути; обтурационная желтуха; холедохолитиаз. 